6-1999

\title{
Tocqueville and Democracy in America: Introduction
}

Joel A. Lieske

Cleveland State University, j.lieske@csuohio.edu

Follow this and additional works at: https://engagedscholarship.csuohio.edu/clpolsci_facpub

How does access to this work benefit you? Let us know!

Publisher's Statement

Copyright 1999 Cambridge University Press. Available on publisher's site at

http://www.jstor.org/stable/420547.

\section{Original Citation}

Lieske, Joel. 1999. "Tocqueville and Democracy in America: Introduction." PS: Political Science and Politics 32:195-196.

\section{Repository Citation}

Lieske, Joel A., "Tocqueville and Democracy in America: Introduction" (1999). Political Science Faculty Publications. 3.

https://engagedscholarship.csuohio.edu/clpolsci_facpub/3

This Article is brought to you for free and open access by the Political Science Department at EngagedScholarship@CSU. It has been accepted for inclusion in Political Science Faculty Publications by an authorized administrator of EngagedScholarship@CSU. For more information, please contact library.es@csuohio.edu. 


\title{
Tocqueville and Democracy in America
}

\author{
Introduction
}

l $n$ the spring of 1831 , Alexis de Tocqueville, a young French aristocrat, came to America with his best friend, Gustave de Beaumont, to study the new nation's experiment with federal democracy. Some 166 years later, from April 1997 to March 1998, C-SPAN retraced the friends' journey in a televised series, "Tocqueville in America." The network's coverage brought back to our attention the work of this remarkable observer of the young United States and his monumental study, Democracy in America. As "The Network of Political Record," C-SPAN is one channel that many political scientists find important, if not essential, to follow. And, certainly, one impetus for this collection of essays was the participation of several contributing authors in this ambitious and well-received project.

Another was the realization that even though Tocqueville is generally viewed as a preeminent authority on American democracy, few political by

Joel Lieske,

Cleveland State University scientists have read his two-volume treatise in its entirety. We may know that Democracy in America is profound and seminal, that it is liberally quoted by elected officials and academics, and that it established Tocqueville's professional reputation, both in America and in Europe, and earned his admission to the French Academy. But our understanding of him and his work often borders on the superficial.

Yet another contemporary stimulus for looking at Tocqueville again was President Clinton's appointment in 1997 of a special "Advisory Committee on Race and Ethnicity." Although this committee was created, ostensibly, to generate a national dialogue on race, with the exception of isolated and largely staged "town" meetings, this laudable objective has yet to be realized. Nevertheless, as Tocqueville pointed out, race was, and continues to be, a fundamental and fundamentally divisive issue in American society.

Finally, it seems appropriate, as we ap- proach the next millennium, to take stock of who we are as a "nation," where we come from, where we appear to be headed, and what actions, if any, are needed to ensure our democratic future.

What the contributors to this symposium try to do, above all, is to take fresh approaches that add to our understanding of Tocqueville, the "student" who came to study American democracy, and what he learned about his subject that is important for us and our students to understand. Clearly, the two subjects, "Tocqueville" and "Democracy in America," cannot be easily separated for reasons that go well beyond simple authorship. He is intellectually complex and difficult to comprehend, fundamentally conservative in his values but liberal and progressive in his ideals.

As the scion of a proud French-Norman family loyal to the monarchy, Tocqueville had been raised in the aristocratic tradition, and tutored by the "good abbé Lesueur," who taught him, as his father before the Revolution, the virtues of religion, morality, and order (Pierson 1959, 7). From a stimulating series of post-graduate lectures given by Professor Guizot-"one of the greatest of the Doctrinaires"-that Tocqueville and Beaumont attended in Paris as young magistrates, he was filled with the ideals of liberty, equality, and social progress (11).

Later, while writing Democracy, he rounded out his formal education by reading the great masterpieces of world literature, including the works of Plato, Aristotle, Plutarch, Machiavelli, Rabelais, Cervantes, and Rousseau; The Federalist Papers; and even the Koran, which reportedly repelled him (449). But his maternal grandparents and a great grandfather had been executed during the Reign of Terror, and his parents barely escaped the same fate. So we find in Tocqueville a type of liberalism-moderate, intellectual, and controlled-that is quite congenial and engaging, whether we consider ourselves left of center, right of center, or middleof-the-road. 


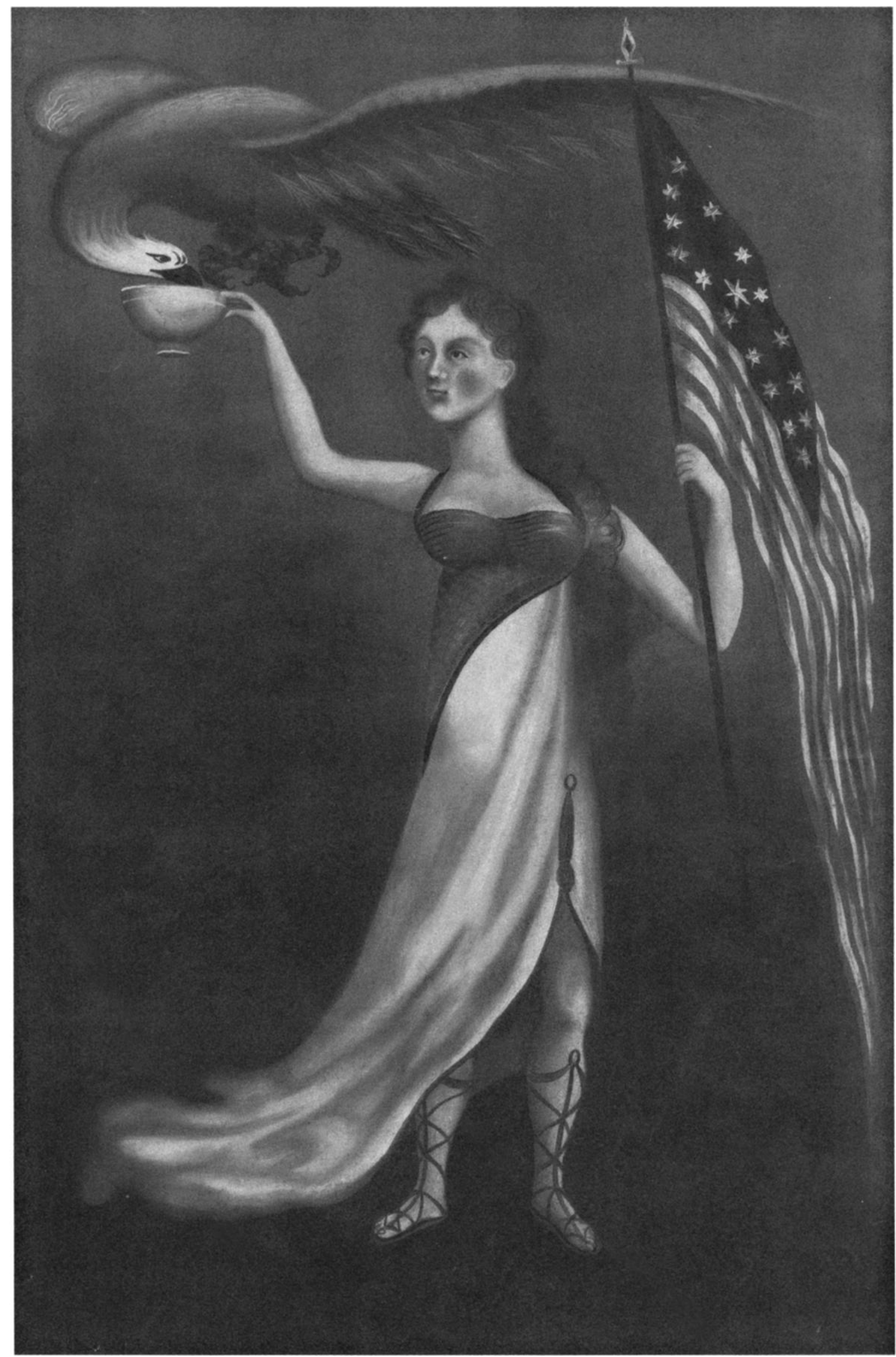

Photo courtesy of Library of Congress. 


\section{Contributing Essays}

The first two essays in this symposium focus on Tocqueville, his American journey, and C-SPAN's "Tocqueville in America." The final three essays draw out and explore his ideas on three themes central to Democracy in America and, ultimately, the success of the American democratic experiment itself: political culture, federalism, and race relations.

The first essay in this collection is by John Splaine, an American educator and historian, who acted as a special consultant to C-SPAN director Brian Lamb for the Tocqueville project and admits to having read Democracy 14 times. Splaine explains why C-SPAN directors initiated the Tocqueville project, the syncretistic process-combining a visual medium with Tocqueville's written words-they employed, the pains they took to ensure historical accuracy, and what they hoped discriminating viewers would learn from the Tocqueville series.

The second essay is by Stephen Frantzich, an habituated C-SPAN "Congress-watcher" who also served as a special consultant on the Tocqueville project and played an instrumental role in putting together the network's Internet teaching modules (www.c-span.org/classroom/ lessonplans/module1.htm). Frantzich shows how C-SPAN, a network that is dedicated to the educational enterprise, orchestrated a highly innovative campaign to connect college and high school students with the "ancient" Tocqueville and make his ideas and "scientific" methodology come alive in the classroom.

The third essay is by Daniel Elazar, a longtime "student" of American political culture and federalism. Elazar makes a persuasive and compelling argument for interpreting Tocqueville as "a philosopher who looked to culture and the institutions shaped by culture as the keys to understanding the political and social worlds." Unlike contemporary thinkers, Elazar argues, Tocqueville did not distinguish between civil society and the state, and thus follows in the American political tradition of viewing government as the "most comprehensive voluntary association" of civil society, "and not as that segment of voluntary public space between the reified state and the private realm."

The fourth essay is by John Kincaid, a student of American federalism and a former executive director of the U.S. Advisory Commission on Intergovernmental Relations. Kincaid points to the central role that Tocqueville assigned to decentralization in the American democratic experiment and how, in Tocqueville's view, Americans learn democracy not by reading about it or studying it, but by taking advantage of the widespread opportunities for democratic participation afforded by a federal system that now consists of some 86,000 units of state and local government.

In the final essay, I pick up on a theme that attracted my interest as a graduate student many years ago-

American race relations. I explore what Tocqueville had to say about the American race dilemma, the new challenges to the democratic experiment that are posed by our growing racial-ethnic and religious diversity, and how the long-term future of American democracy may depend as much on human nature and our ability to forge a new democratic "nation" as on the system of checks and balances designed by the Founders to protect individual liberty and guard against political tyranny.

\section{References}

Pierson, George Wilson. 1959. Tocqueville in America. Garden City, NY: Doubleday.

\section{Symposium Contributors}

Daniel J. Elazar is professor of political science at Temple University, where he directs the Center for the Study of Federalism. He is also founder and president of the Jerusalem Center for Public Affairs and holds the Senator N.M. Paterson Professorship in Intergovernmental Relations at Bar Ilan University in Israel, where he heads the Institute for Local Government. He has written or edited over 65 books and many other publications, ranging from an analysis of local governments in the U.S. Midwest to a handbook on federal systems throughout the world.

Stephen Frantzich is professor and chair of the department of political science at the U.S. Naval Academy. A Ph.D. from the University of Minnesota, he has written widely on the impact of technology on politics. His most recent books are: The C-SPAN Revolution (University of Oklahoma Press, 1996) and Making a Difference: Citizen Activists in a Cynical Age (Rowman and Littlefield, forthcoming).

John Kincaid is the Robert B. and Helen S. Meyner Professor of Government and Public Service and director of the Meyner Center for the Study of State and Local Government at Lafayette College. He is also editor of Publius: The Journal of Federalism and author of various works on federalism and intergovenmental relations.

Joel Lieske is a professor of political science at Cleveland State University. In his spare time he likes to play basketball with his students and coach his kids' basketball, soccer, and baseball teams.

John Splaine is an associate professor in the department of education policy, planning and administration at the University of Maryland. He has taught courses in the politics of education and the philosophy and history of education. He served as the historical consultant for C-SPAN's project on Alexis de Tocqueville and the book that resulted, Traveling Tocqueville's America (Johns Hopkins University Press, 1998). 